\title{
Mine reclamation period to successfully meet criteria in Indonesia
}

\author{
F Amanah Ministry of Energy and Mineral Resources, Republic of Indonesia \\ T Yunanto Ministry of Energy and Mineral Resources, Republic of Indonesia
}

\begin{abstract}
To minimise the effects of coal mining, decent environmental management is necessary to stabilise the land so it is productive after mine closure. The Ministry of Energy and Mineral Resources (MEMR) regulates that a mine reclamation plan is mandatory for the mine permit holder. This is a requirement of the permit application. Once the mine reclamation plan is approved, the mine permit holder has to place a bond in the national bank to cover the mine reclamation costs. MEMR also sets out the criteria for successful reclamation to be accomplished by the mine reclamation program. This includes area compliance, land re-contouring, revegetation and final completion. This research aimed to discover what mine reclamation period is required to successfully meet the criteria. The data was taken from the results of evaluations conducted by MEMR between 2009 and 2018 for 30 coal companies with a total of 277 reclamation areas. The data was analysed with Kruskal-Wallis ANOVA and Mann-Whitney test using STATISTICA 13.0 software. The data showed that, based on the criteria, successful reclamation criteria were most achieved in six years (i.e. $35.63 \%$ of the 277 reclamation areas). The data also showed that, for most companies, canopy cover is the most difficult criterion to achieve. Species selection and plant spacing were factors affecting achievement of the canopy cover criterion.
\end{abstract}

Keywords: coal mining, reclamation, successful criteria, canopy cover

\section{Introduction}

As the largest energy producer and consumer in southeast Asia, Indonesia has rich potential non-renewable (coal, oil and gas) and renewable (hydro, geothermal and solar) energy resources. Energy, including coal, is projected as one of the main streams of national income from taxable and non-taxable revenue (Ministry of Energy and Mineral Resources [MEMR] 2015). Domestic consumption of coal increased from 76 million tonnes in 2014 to 115 million tonnes in 2018 (Figure 1). In response to the national energy policy, the Indonesian government improved coal production for domestic use. Coal use as an electricity source is projected to rise from 2015 to 2025. 


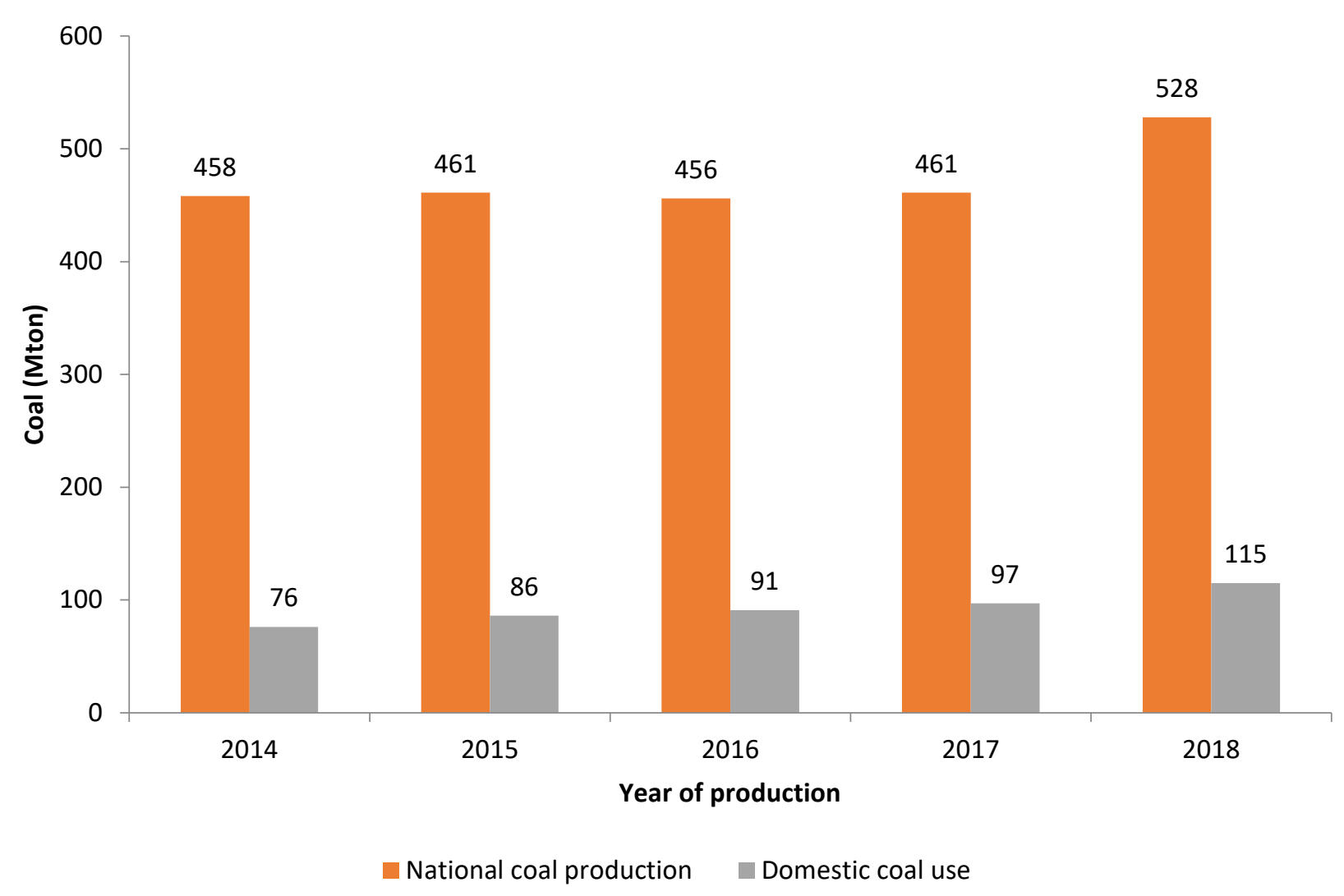

Figure 1 National coal production, 2014-2018 (modified from MEMR 2019)

As open pit mining of coal is widely used in Indonesia, several environmental impacts need to be regulated and prevented. Hidayat et al. (2015) reported that open pit mining caused land use, morphological and landscape changes in Luwu Timur Regency.

\subsection{Mine reclamation}

The Good Mining Practice Implementation Guidelines (MEMR 2018) determine that mine reclamation is an activity that aims to restore and improve the ex-mining area's environmental quality and ecosystem in accordance with its land use, commencing during the mining operation phase. The mine reclamation planning process begins during the exploration phase and the mine permit applicant has to submit a mine reclamation plan and a mine closure plan before obtaining the operation permit. Figure 2 outlines the process. 


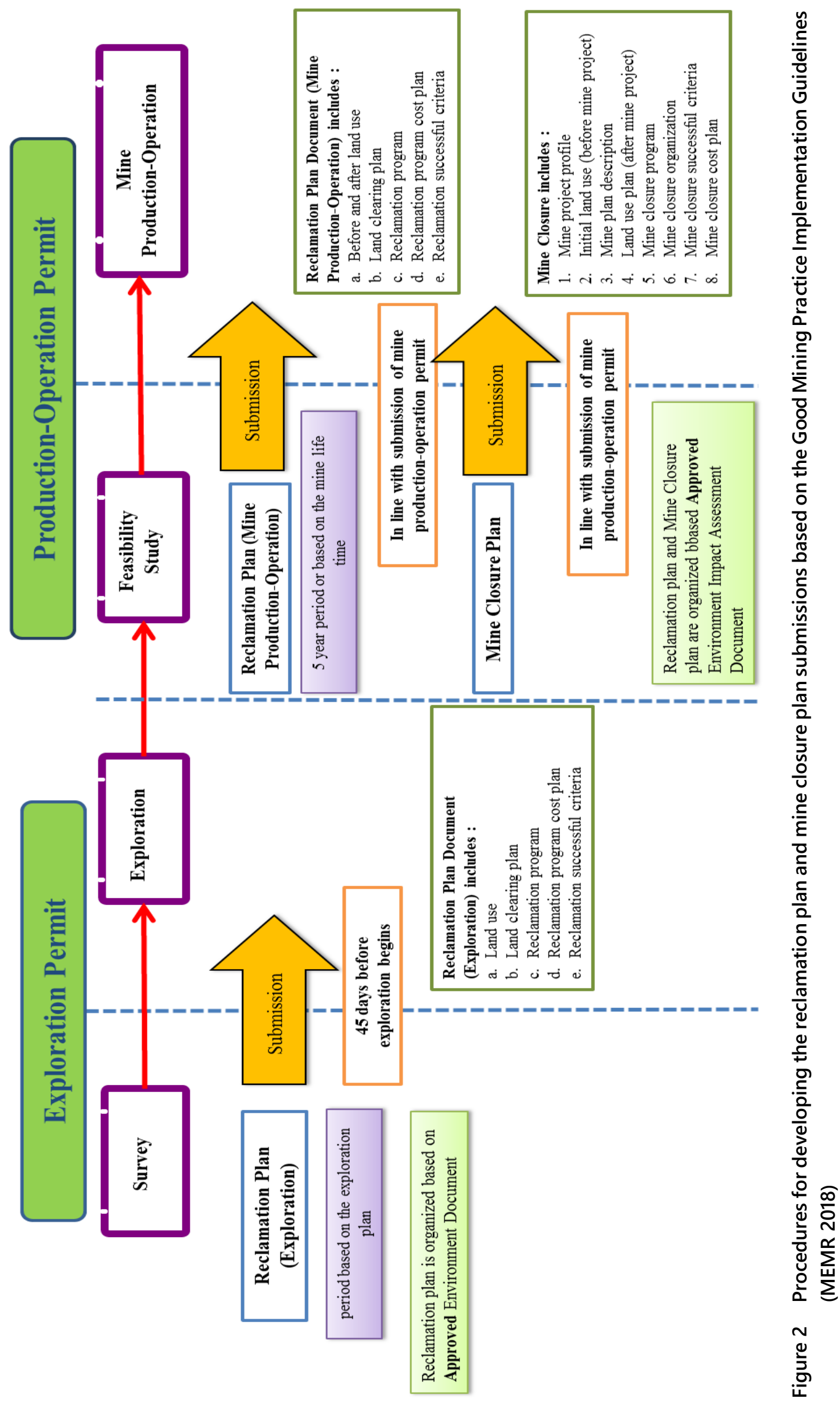


The mine reclamation plan includes the land use, land clearing plan, mine reclamation program, mine reclamation cost and mine reclamation criteria for success (successful criteria). Since mine reclamation aims to rehabilitate the ex-mining land based on the land use, the mine reclamation program considers the final land use as either a revegetation area or other land use. It is allowed to reform the reclamation area for cultivation or livestock, housing, tourism and water intake purposes, with the provision that it is not in the forest area.

Generally, the permit applicant includes the mine reclamation and revegetation program in the submission. The program consists of land re-contouring, soil spreading, erosion control, water management, plantation (cover crop, pioneer tree and intermediate tree species, preferably using local species) and revegetation maintenance. Revegetation maintenance includes fertilisation, pest and weed control, replanting, erosion and sedimentation control, and revegetation access control. The revegetation program is scheduled for a minimum of three years. The permit holder also submits a void management program including slope stabilisation, void safety, water monitoring and void maintenance.

\subsection{Mine reclamation bond}

A bond is submitted with the mine reclamation plan. The bond is based on the mine reclamation program costs, including future value. The bond is released in accordance with the percentage of the successful criteria met, which is based on periodical evaluation by MEMR. After the evaluation, the approved percentage of met criteria is translated to a percentage of the bond, the rest of which is kept in the bank. If the reclamation costs are more than the bond, the permit holder is responsible for meeting the deficiency.

\subsection{Mine reclamation successful criteria}

The MEMR mine reclamation annual assessment has two objectives: evaluating completion of reclamation of an area and how much of the successful criteria has been fulfilled. Achievement of these objectives is based on the mine reclamation plan submitted by the permit holder. The mine reclamation plan establishes the area which has to be rehabilitated each year. In the annual assessment, fulfilment of the rehabilitation area is evaluated against the plan. The Good Mining Practice Implementation Guidelines (MEMR 2018) determine the mine reclamation successful criteria to be achieved. This is shown in Table 1.

Table 1 Mine reclamation success criteria (MEMR 2018)

\begin{tabular}{lll}
\hline No & Successful criteria & Percentage (\%) \\
\hline 1 & Land re-contouring & \\
& Land surface contouring & 40 \\
& Top soil spreading & 10 \\
& Erosion control and water management & 10 \\
\hline 2 & Revegetation & \\
& Cover crop growth & 2.5 \\
& Fast-growing trees growth & 7.5 \\
& Local (intermediate/under-shelter) trees growth & 5 \\
& Acid mine drainage control & 5 \\
3 & Final completion & \\
& Canopy or crown cover & 10 \\
& Maintenance & 10 \\
\hline
\end{tabular}


The formula to calculate the successful mine reclamation score is:

$$
T S=\% A C \times \% Q A
$$

where:

$$
\begin{aligned}
& \mathrm{TS}=\text { total score of successful mine reclamation. } \\
& \mathrm{AC}=\text { area completion. } \\
& \mathrm{QA}=\text { quality achievement based on Table } 1 .
\end{aligned}
$$

In general, percentage points for land re-contouring are achieved in the first year of reclamation. Land re-contouring is performed by mining engineers and must be assessed as meeting the successful criteria before the cover crop, pioneer (fast-growing) species and intermediate/under-shelter species are planted. It is preferred that tree and plant species are local species, or introduced species that are considered as local species. Failure in land re-contouring is one factor that can inhibit successful revegetation. Therefore, the criteria that are hardest to meet are related to tree growth and plantation, revegetation maintenance and canopy cover formation.

Most permit holders propose three years as the time estimated to meet the criteria by the end of the period. Trees require sufficient time to create the canopy cover, and this can be successfully achieved in three years if there are no replanting and soil issues. Successful reclamation is depicted in Figure 3.

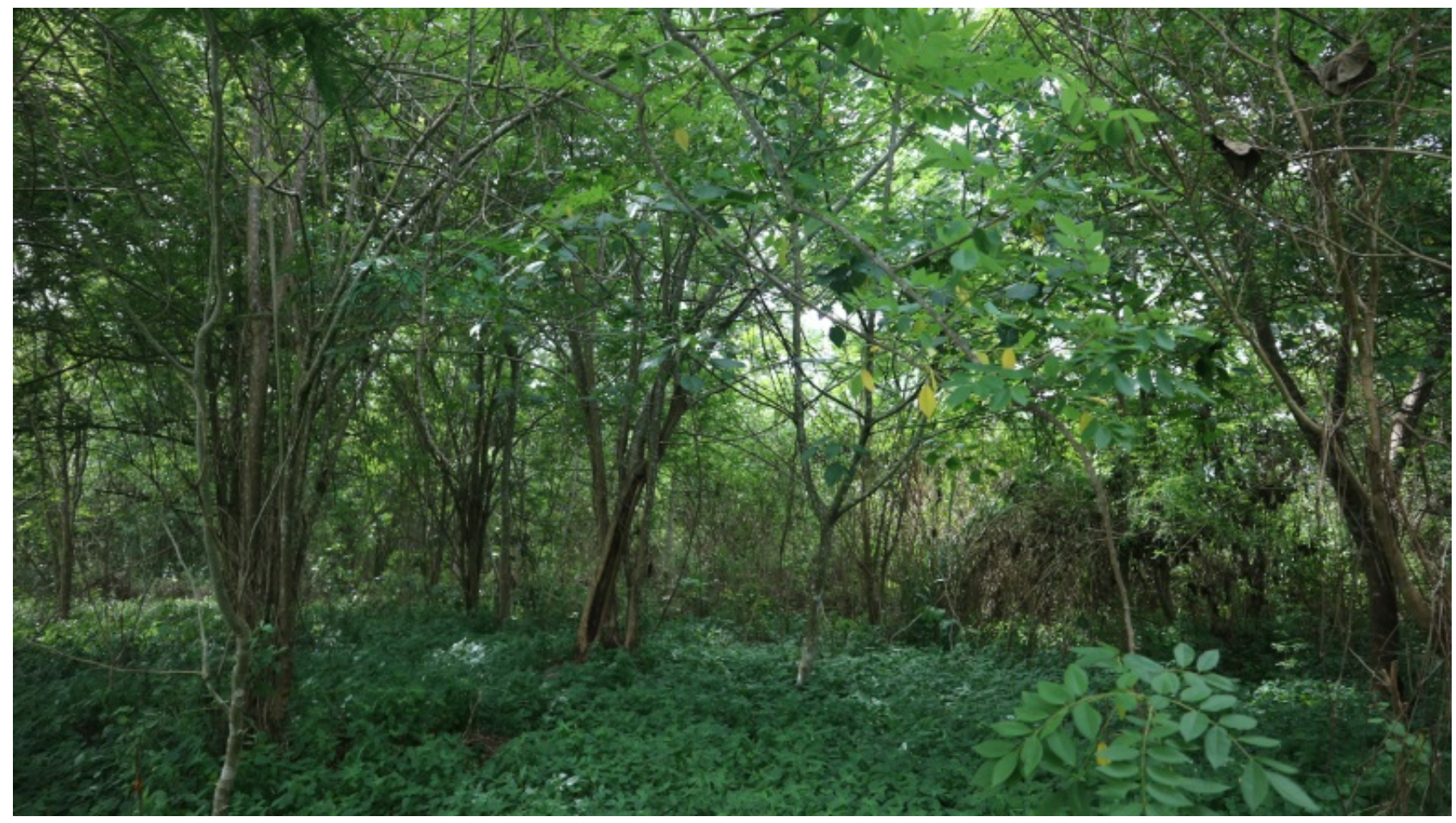

Figure 3 Mine reclamation area that has met the success criteria, PT Indominco Mandiri, East Kutai Regency, East Kalimantan Province

Figure 3 shows a mine reclamation area that was planted in 2012 and evaluated in 2018 (it needs six years to meet the criteria). Although most permit holders meet the criteria before the planned maintenance period ends, the rest of the mine reclamation cost is still their responsibility. The mine reclamation is still undertaken during operation phase so its cost deviation can be prevented. 


\section{$1.4 \quad$ Objective}

The objective of this research was to define the mine reclamation period necessary to meet the successful criteria based on the Good Mining Practice Implementation Guidelines (MEMR 2018).

\section{Methodology}

\subsection{Research area}

Land reclamation is supervised and evaluated by MEMR, or the Department of Energy and Mineral Resources (DEMR) in the province based on the permit release. This research was conducted in 30 coal mining companies under the authority of MEMR, with a range of 6-10 areas from each company per reclamation year and a total of 277 areas (or blocks) between 2008 and 2017. The mine reclamation period for each company is based on when the permit was released and the start date of the reclamation, and differs between companies.

\subsection{Data}

The data used in this research is from the annual mine reclamation evaluation conducted by MEMR. The data was collected from the evaluation history of 30 coal mining companies (Coal Contract of Work/PKP2B holder) between 2009 and 2018. The data contained the percentage of success criteria met every year and the requirement period to accomplish the criteria (Table 1). The data was also taken from revegetation areas that were rehabilitated from 2008 to 2017. Any mine reclamation issues were also collected to assist with information for improvement in the near future.

\subsection{Statistics}

The data analysed in this paper was the successful criteria percentage history based on the annual MEMR mine reclamation evaluation. The reclamation areas of the 30 mine companies had different numbers of blocks (i.e. areas), different starting points (by year) for their reclamation activities and different numbers of blocks that fulfilled the successful mine reclamation criteria. The total reclamation area for the 30 mine companies was 277 blocks. The data history included scores for pioneer tree plantation, intermediate/undershelter species plantation, canopy cover formation and total accomplishment. The reclamation areas (blocks) of the mine companies which had fulfilled the successful criteria were grouped by year of reclamation age: for example, 1st year, 2nd year, 3rd year, 4th year, 5th year, 6th year, 7th year and above 7th year. The data was then analysed descriptively and comparisons drawn between groups with Kruskal-Wallis ANOVA and Mann-Whitney tests using STATISTICA 13.0.

\section{Results and discussion}

The data in Table 2 shows that pioneer trees grew rapidly and successfully (45.13\%). Most coal companies cultivate Enterolobium cyclocarpum. It is fast growing and can grow on ex-mining land and enrich the soil through nitrogen fixation (Syarif 2008). Yunanto (2018) also reported that E. cyclocarpum is selected because it can grow to more 15 metres in four years and has good canopy cover. It can grow to 30 metres in height and 3.5 metres in diameter (Husodo et al. 2014). Paraserianthes falcataria are also planted as pioneer trees because they can rapidly grow on marginal soil in young stands (Krisnawati et al. 2011). 
Table 2 Comparison between the reclamation areas that have been successful and those that have not been successful for the four criterion which are the most difficult to meet; i.e. pioneer tree growth, intermediate tree growth, canopy cover and revegetation maintenance.

\begin{tabular}{lll}
\hline Successful criteria & Met full criteria (\%) & Have not met full criteria (\%) \\
\hline Successful (total) & 31.41 & 68.59 \\
Pioneer trees & 45.13 & 54.87 \\
Intermediate trees & 34.66 & 65.34 \\
Canopy cover & 27.44 & 72.56 \\
Revegetation maintenance & 31.41 & 68.59 \\
\hline
\end{tabular}

In general, reclamation areas require six years to meet all the criteria (Table 3 ). According to the Kruskal-Wallis ANOVA and Mann-Whitney test with STATISTICA 13.0, reclamation areas attain 100\% in 5-6 years (Figure 5).

Table 3 Descriptive statistical analysis of reclamation areas that meet the successful (total) criteria in number of years

\begin{tabular}{llll}
\hline Period & Number of companies & Number of reclamation area (\%) & Standard deviation \\
\hline 1 year & 30 & 0.00 & 0.00 \\
2 years & 30 & 0.00 & 0.00 \\
3 years & 30 & 1.44 & 0.35 \\
4 years & 30 & 11.49 & 0.61 \\
5 years & 30 & 28.74 & 1.12 \\
6 years & 30 & 35.63 & 1.22 \\
7 years & 30 & 16.09 & 0.86 \\
$>7$ years & 30 & 3.45 & 0.31 \\
\hline
\end{tabular}

In general, the coal mine companies met the pioneer trees growth criteria in four years (i.e. $33.60 \%$ of the number of reclamation areas; Table 4). This is due to the selection of fast-growing species as pioneer trees.

Table 4 Descriptive statistical analysis of reclamation areas that meet the successful criteria of pioneer trees in number of years

\begin{tabular}{llll}
\hline Period & Number of companies & Number of reclamation area (\%) & Standard deviation \\
\hline 1 year & 30 & 0.80 & 0.18 \\
2 years & 30 & 10.40 & 0.77 \\
3 years & 30 & 21.60 & 0.96 \\
4 years & 30 & 33.60 & 1.13 \\
5 years & 30 & 19.20 & 0.71 \\
6 years & 30 & 9.60 & 0.67 \\
7 years & 30 & 4.80 & 0.41 \\
$>7$ years & 30 & 0.00 & 0.00 \\
\hline
\end{tabular}


In most cases, the intermediate/under-shelter tree species planting criteria was attained in the fifth year of evaluation with $30.21 \%$ (Table 5). However, statistical analysis shows that the intermediate/under-shelter tree species planting was achieved in 4-6 years (Figure 5). Generally, intermediate species are planted when the pioneer's canopy cover has formed, meaning that it is planted in the second or third year following pioneer plantation.

Table 5 Descriptive statistical analysis of reclamation areas that met the successful criteria of intermediate/under-shelter trees in number of years

\begin{tabular}{llll}
\hline Period & Number of companies & Number of reclamation area (\%) & Standard deviation \\
\hline 1 year & 30 & 1.04 & 0.18 \\
2 years & 30 & 1.04 & 0.18 \\
3 years & 30 & 11.46 & 0.61 \\
4 years & 30 & 26.04 & 1.05 \\
5 years & 30 & 30.21 & 1.19 \\
6 years & 30 & 17.71 & 0.82 \\
7 years & 30 & 11.46 & 0.76 \\
$>7$ years & 30 & 7.69 & 0.18 \\
\hline
\end{tabular}

The most difficult criterion to meet was canopy cover, with only $27.44 \%$ of 277 areas fully meeting this criterion between 2014 and 2018 (canopy cover first became one of the mine reclamation successful criteria in 2014). Species selection and plant spacing are factors that may affect the complete achievement of canopy cover (Figure 4). The architecture model of species selection influences canopy cover: for example, the selection of species with Troll's model Samanea saman and Albizia procera; Rauh's model Ficus benjamina; and Aubreville's model Terminalia catappa (Hasanuddin 2013; Gustini et al. 2017).

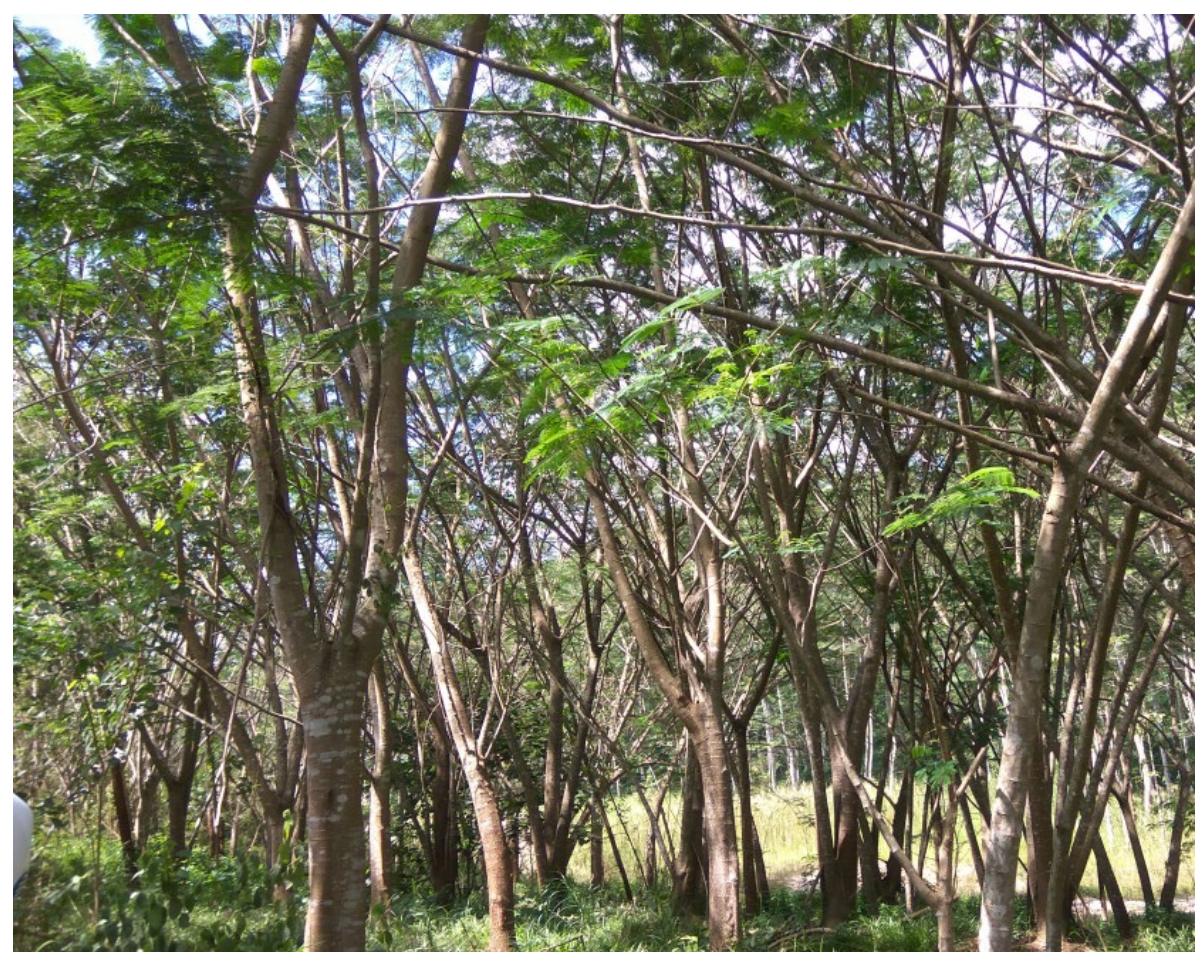

Figure 4 Complete canopy cover achieved in PT Kideco Jaya Agung, Paser Regency, East Kalimantan Province (planted in 2011 and based on the 2017 evaluation result) 
Generally, revegetation on ex-mining land begins with cover crop planting to control the erosion caused by high precipitation. After cover crop plantation, fast-growing pioneer species are planted. The Fabaceae family is mostly planted on the reclamation areas because it is able to associate with bacteria which can bind the soil nitrogen. However, shade tolerant intermediate species (e.g. Vitex cofassu, Peronema canescens and Anthocephalus macrophyllus) can also be planted with the pioneer species in the first year. After 2-3 years, when the pioneer species has formed the canopy cover, most under-shelter species are planted. The plants are mainly local species and introduced species which are considered local species, such as Tectona grandis and Swietenia macrophylla. Later, the revegetation maintenance is carried out until all the successful criteria have been met.

Importantly, plant spacing of pioneer trees can increase the total canopy cover per hectare. On some sites, the plant spacing generally used for E. cyclocarpum, P. falcataria and S. saman was $4 \mathrm{~m} \times 4 \mathrm{~m}$. However, planting pioneer and intermediate species with smaller spacing (e.g. $3 \mathrm{~m} \times 3 \mathrm{~m}$ ) accelerates canopy cover formation. The aim of canopy formation is to accommodate natural regeneration. The canopy cover is mostly complete in six years with $32.89 \%$, but statistically (based on Kruskal-Wallis ANOVA and Mann-Whitney test), canopy cover is fulfilled in the reclamation period of 5-7 years (Table 6 and Figure 5).

Table 6 Descriptive statistical analyses of reclamation areas that meet the successful criteria of canopy cover in number of years

\begin{tabular}{llll}
\hline Period & Number of companies & Number of reclamation area (\%) & Standard deviation \\
\hline 1 year & 30 & 1.32 & 0.18 \\
2 years & 30 & 0.00 & 0.00 \\
3 years & 30 & 1.32 & 0.18 \\
4 years & 30 & 14.47 & 0.85 \\
5 years & 30 & 28.95 & 0.87 \\
6 years & 30 & 32.89 & 1.12 \\
7 years & 30 & 17.11 & 0.86 \\
$>7$ years & 30 & 3.95 & 0.31 \\
\hline
\end{tabular}

Completion of revegetation maintenance mostly occurred in the sixth year of evaluation with 33.33\% (Table 7). It takes 5-6 years to meet full criteria based on Kruskal-Wallis ANOVA and Mann-Whitney test statistical analysis using STATISTICA 13.0 (Figure 5).

Table 7 Descriptive statistical analyses of reclamation areas that meet the successful criteria of revegetation maintenance in number of years

\begin{tabular}{llll}
\hline Period & Number of companies & Number of reclamation area (\%) & Standard deviation \\
\hline 1 year & 30 & 0.00 & 0.00 \\
2 years & 30 & 0.00 & 0.00 \\
3 years & 30 & 4.60 & 0.35 \\
4 years & 30 & 14.94 & 0.63 \\
5 years & 30 & 27.59 & 1.03 \\
6 years & 30 & 33.33 & 1.19 \\
7 years & 30 & 16.09 & 0.86 \\
$>7$ years & 30 & 3.45 & 0.31 \\
\hline
\end{tabular}




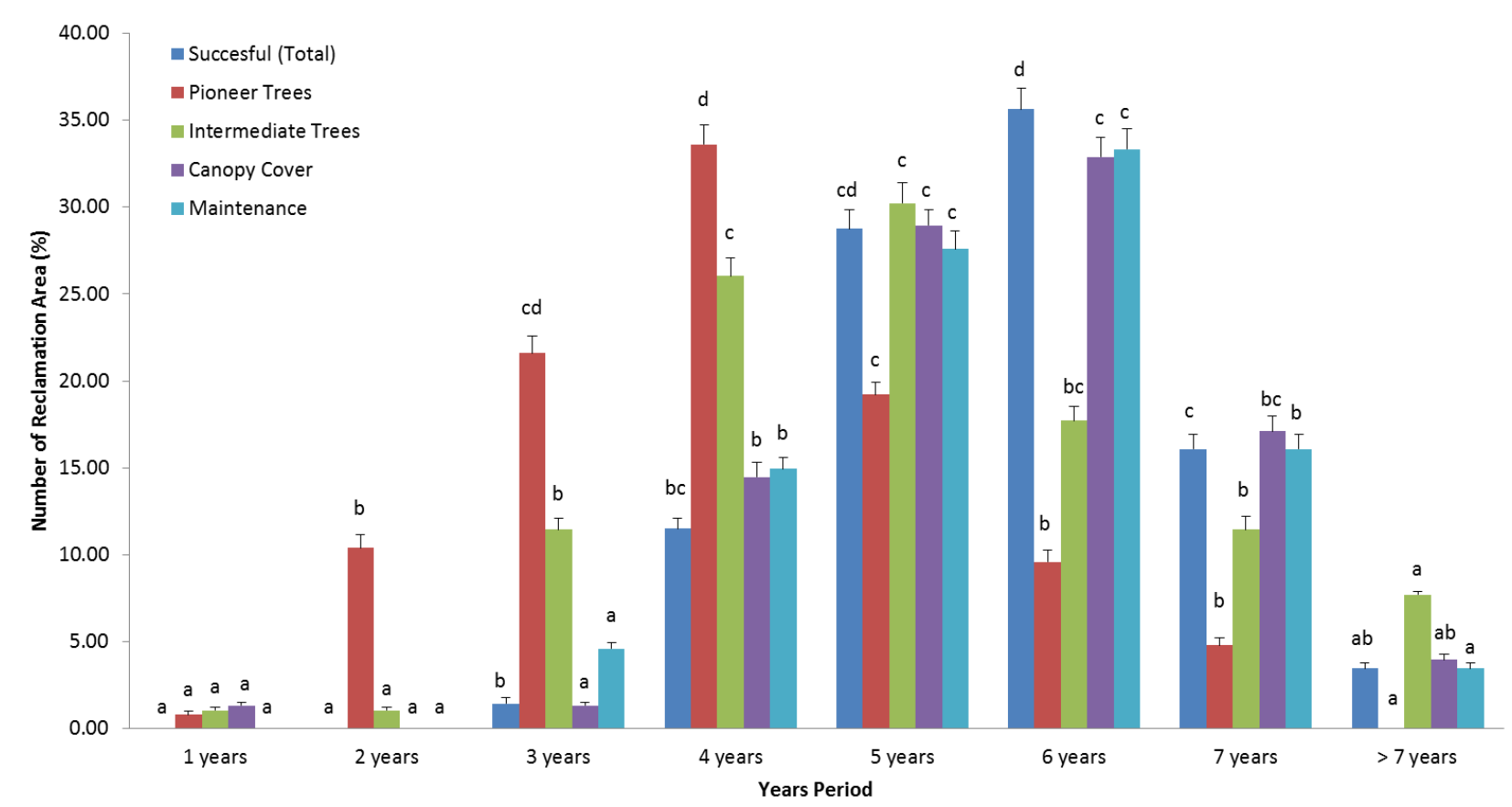

Figure 5 Comparison of reclamation areas that meet the total successful criteria and the four criteria relating to revegetation, by number of years, with the Kruskal-Wallis ANOVA test, and compared using the Mann-Whitney $U$ test for all criteria (all results were significant difference at $\mathrm{p}=0.0000)$

Many factors impact successful mine reclamation. In general, permit holders need to consider some factors that influence this achievement. These are:

1. Landslides

Landslides occurring in the reclamation area (mostly on out-pit dumps) can extend the duration of mine reclamation. In this case, reshaping the land surface should be undertaken and the planting restarted. The permit holder should accurately design the slope stability, with overburden material type considered to determine the maximum slopes (New York State Department of Environmental Conservation Division of Mineral Resources 2005). In addition, Haryanto \& Basuki (2006) state that material strength and groundwater should be considered to determine the slope stability. Slope geometry, surface runoff, dynamic load and dumping rate are also factors of slope stability (Directorate General of Mineral and Coal [DGMC] 2014). A hydrologic map is essential to understand the surface runoff, and to design erosion control mechanisms such as drainage, sediment trap, and drop structure (Ministry of Environment and Forestry [MoEF] 2019).

Moreover, the permit holder should conduct periodical geotechnical monitoring of the slope stability, in addition to monitoring the mine reclamation areas, by both visual and instrumental methods, such as total station, radar, extensometer and inclinometer. In addition, groundwater level monitoring should also be carried out. Risk assessment and alarm threshold criteria can be applied to assess the risk level and control (DGMC 2014).

2. Soil content

Soil in the mine reclamation is a mixture of topsoil and subsoil that can be directly spread or temporarily stocked. Generally, soil is spread with a thickness of $30-50 \mathrm{~cm}$ over the reclamation area. Yunanto (2018) stated that the under 10-year-reclamation areas in East Kalimantan Province 
had high clay content above $38 \%$, while the secondary natural forest has $26.18 \%$ of clay content. High clay content is well known to affect root growth pattern. A lot of work is required to solve problems with soil since it is the media of tree growth. Soil availability for mine reclamation is another issue. In many cases, the coal companies lack soil, so they plant the trees using either a potting system or direct planting, which may diminish the likelihood of successfully meeting the criteria. Good top soil management is essential because it can prevent nitrogen losses and enhance soil nutrient and microbes, and cover crop planting and drainage systems assist in erosion control (Sheoran et al. 2010).

3. Species selection

The permit holder has to decide what the appropriate pioneer and intermediate tree species and planting density will optimise canopy growth and cover. The suitability of the soil content is also a factor to consider in species selection. There are some coal companies which mainly plant the intermediate trees, but these require more time to grow in order to have biodiversity enrichment. The listed species in Table 8 are advised species to be planted on mine reclamation in forestry area.

Table 8 Advised intolerant species (MoEF 2019)

\begin{tabular}{|c|c|c|c|}
\hline Species & Note & Species & Note \\
\hline Paraserianthes falcataria & $\begin{array}{l}\text { Local (eastern } \\
\text { Indonesia) }\end{array}$ & Cananga odorata & $\begin{array}{l}\text { Local (Indonesia) } \\
\text { and exotic }\end{array}$ \\
\hline Enterelobium cyclocarpum & Exotic & Anthocephalus macrophyllus & Local (Indonesia) \\
\hline Cassia siamea & Local (Indonesia) & Anthocephalus cadamba & Local (Indonesia) \\
\hline Adenathera pavonina & Local (Indonesia) & Macaranga spp. & Local (Indonesia) \\
\hline Samanea saman & Exotic & Mallotus spp. & Local (Indonesia) \\
\hline Casuarina spp. & Local (Indonesia) & Trema spp. & Local (Indonesia) \\
\hline Eucalyptus spp. & $\begin{array}{l}\text { Local (Indonesia) } \\
\text { and exotic }\end{array}$ & Duabanga moluccana & Local (Indonesia) \\
\hline Melaleuca cajuputi & Local (Indonesia) & Octomeles sumatrana & Local (Indonesia) \\
\hline Melaleuca spp. & Local (Indonesia) & Gmelina arborea & Exotic \\
\hline
\end{tabular}

4. Manpower

Generally, maintenance failure comes from insufficient manpower. The permit holder has to figure out how much manpower is required to conduct the maintenance program. Worker competency is also an important factor; for example, awareness of soil quality and proper species selection, especially considering $\mathrm{pH}$, heavy metals, soil moisture are often deficient.

5. External interference

Some reclamation areas are interfered by illegal logging, illegal mining and land use modification by the land owner (people around the mining sites); for example conversion to housing, livestock, etc., before the agreement. Generally, the conversion is incidental, occurring after the tree planting, and was not reported in the mine reclamation document. 
The permit holders generally schedule three years for revegetation maintenance in the mine reclamation plan; this is adequate to determine its time sufficiency. Coal companies should note that species selection and plant spacing are factors that affect successful completion of the criteria (particularly relating to canopy cover).

\section{Conclusion}

Most reclamation areas met the mine reclamation successful criteria in six years (i.e. $35.63 \%$ of 277 reclamation areas) after plantation. However, the data also showed that the companies found canopy cover the most difficult to achieve (27.44\% of 277 areas). As a result, it is recommended to look at species selection and plant spacing as key the factors in successfully meeting the criteria. In addition, the factors of landslide, soil fertility, manpower sufficiency and probability of external interference also have to be overcome in order to successfully fulfil the criteria in less than seven years.

\section{Acknowledgement}

My sincere thanks to Mr Sri Rahajo, Director of Engineering and Environment Mineral and Coal, MEMR, Mr Ahmad Syauqi, Ms Tiyas Nurcahyani and Mr Jajat Sudrajat who supported me during this study.

\section{References}

Directorate General of Mineral and Coal 2014, Pedoman Teknis Pemantauan Kestabilan Lereng Tambang Dan Timbunan Batuan Penutup, Directorate General of Mineral and Coal, Jakarta

Gustini, E, Indriyani, S \& Azrianigsih, R 2017, 'Model arsitektur percabangan beberapa pohon di Taman Nasional Alas Purwo', Jurnal Biotropika, vol. 5, no. 1, pp. 27-35.

Haryanto, L \& Basuki, S 2006, 'Analisis kestabilan lereng timbunan overburden: Studi kasus Desa Kampung Baru Kecamatan Cempaka Banjarmasin', Info Teknik, vol. 7 no. 1, pp. 41-47.

Hasanuddin 2013, 'Model arsitektur pohon hutan kota banda aceh sebagai penunjang praktikum morfologi tumbuhan', Jurnal EduBio Tropika, vol. 1, no. 1, pp. 38-44.

Hidayat, W, Rustiadi, E \& Kartodiharjo, H 2015, 'Dampak pertambangan terhadap perubahan penggunaan lahan dan kesesuaian peruntukan ruang (studi kasus Kabupaten Luwu Timur, Provinsi Sulawesi Selatan', Jurnal Perencanaan Wilayah dan Kota, vol. 26, no. 2, pp. 130-146.

Husodo, T, Irawan, B, Wulandari, I \& Dasanova, WM 2014, POHON di Taman Kota Bandung, Badan Pengelola Lingkungan Hidup Kota Bandung, viewed 1 April 2019, https://www.academia.edu/33124092/POHON_Taman_Kota_Bandung

Krisnawati, H, Varis, E, Kallio M, Kanninen, M 2011, Paraserianthes falcataria (L.) Nielsen Ecology: Silviculture and Productivity, Center for International Forestry Research, Bogor.

Ministry of Energy and Mineral Resources 2019, Booklet Energi Berkeadilan Q4 (Update), Ministry of Energy and Mineral Resources, Jakarta, viewed 10 March 2019, https://www.esdm.go.id/assets/media/content/content-booklet-energi-berkeadilan-4tahun-kinerja-update.pdf

Ministry of Energy and Mineral Resources 2018, Minister of Energy and Mineral Resources of Republic Indonesia's Decree No. 1827.K/30/MEM/2018 regarding Implementation of the Good Mining Practices and Supervision of the Mineral and Coal Mining, Jakarta.

Ministry of Energy and Mineral Resources 2015, Renstra KESDM 2015-2019, Jakarta.

Ministry of Environment and Forestry 2019, Petunjuk Teknis Reklamasi Pasca Tambang pada Kawasan Hutan, Jakarta.

New York State Department of Environmental Conservation Division of Mineral Resources 2005, New York State Revegetation Procedures Manual: Surface Mining Reclamation, New York.

Syarif, F 2008, 'Tolerance of sengon buto (Enterolobium cyclocarpum Griseb) grown on cyanide contaminated tailing media with fertilier application', Berita Biologi, vol. 9, no. 1, pp. 105-110.

Sheoran, V, Sheoran AS \& Poonia, P 2010, 'Soil reclamation of abandoned mine land by revegetation: a review', International Journal of Soil, Sediment and Water, vol. 3, no. 2, pp. 1-20.

Yunanto, T 2018, Site and Vegetation Development after Coal Mine Reclamation in Kalimantan, Indonesia, Cuvillier Verlag, Göttingen. 